\title{
Delineation of Groundwater Potential Zones using Remote Sensing and GIS Techniques in Kanakanala Reservoir Subwatershed, Karnataka, India
}

\author{
R.S. Savita ${ }^{1}$, H.K. Mittal ${ }^{1}$, U. Satishkumar ${ }^{2}$, P.K. Singh ${ }^{1}$, K.K. Yadav ${ }^{1}$, \\ H.K. Jain ${ }^{3}$, S.M. Mathur ${ }^{4}$ and Sham Davande ${ }^{5}$ \\ ${ }^{1}$ Department of Soil and Water Engineering, CTAE, MPUAT, Udaipur, \\ Rajasthan - 313 001, India \\ ${ }^{2}$ Department of Soil and Water Engineering, CAE, UAS, Raichur, Karnataka-584104, India \\ ${ }^{3}$ Department of Agricultural Statistics and Computer Application, RCA, MPUAT, Udaipur, \\ Rajasthan - 313 001, India \\ ${ }^{4}$ Department of Farm Machinery and Power Engineering, CTAE, MPUAT, Udaipur, \\ Rajasthan - 313 001, India \\ ${ }^{5}$ GIS Analyst, FES, Anand, Gujarat, India \\ *Corresponding author
}

\section{A B S T R A C T}

\section{Keywords}

RS, GIS, LULC,

Weighted Index

Overlay Analysis,

Groundwater potential

zones, ArcGIS,

Drainage density etc.

Article Info

Accepted:

04 December 2017

Available Online:

10 January 2018
As the demand and needs of the population towards water is growing the value of water is felt in all sectors. At the same time, surface water resources are becoming insufficient to fulfill the water demand. So that systematic planning of groundwater improvement using modern technique is fundamental for the proper management and utilization of this precious resource. But still groundwater resources have not yet been properly exploited, keeping this in view, the present study has been undertaken to demarcate the groundwater potential zones in Kanakanala Reservoir Subwatershed, Karnataka by using RS and GIS approach. Thematic maps of geology, geomorphology, soil, slope, Land Use/Land Cover (LULC) and drainage density were used and groundwater potential zones were demarcated by Weighted Index Overlay Analysis (WIOA) in Arc GIS 10.1 software. During overlay analysis the ranking has been given for each individual parameter of each thematic map and weights were assigned according to the influence towards groundwater. Finally, four groundwater potential zones were delineated viz., very good, good, moderate and poor. From the study it was concluded that, demarcation of groundwater potential zones helpful for effective recognition of suitable locations for its extraction and better planning and management.

\section{Introduction}

Water is prime requirement for survival of living beings and it plays an important role in the countries like India as its economy predominantly depends on agriculture. With improvement in standard of living and growing number of population, demand for water resources has increased along with reducing availability of water throughout the 
nation. Groundwater is one of the very precious natural resources of earth that sustains all human activities (Chaudhary et al., (1996) and also it is more dynamic renewable natural resource available with good quality and quantity in appropriate time/space.

The demand of groundwater is continuously in the rise because of its several inherent qualities, such as; slow moving, large storage volume, long retention time, could be drawn on demand, less risk free than surface water sources, consistent temperature, continuous availability, excellent natural quality, limited vulnerability, low development cost and drought reliability etc. So that timely and reliable information on the occurrence and movement of groundwater is a prerequisite for meeting its increasing demand for drinking, domestic, industrial sector (Arivalagan et al., 2014). It might be noted that not only its requirement has increased over years but it seems that the demand would never cease (Sitender and Rajeshwari, 2011). Hence, delineation of groundwater potential zones has acquired great significance (Sitender and Rajeshwari, 2011).

According to investigation made by the CGWB (Koppal and Raichur, 2013), annual replenishable groundwater resources (2004) in the Koppal and Raichur district ranged from 701.49 to 820.95 ham. In which net annual groundwater draft was 337.80 to 262.8 ham. As depth to water level is considered it was ranges between $0.65-10.70(\mathrm{~m} \mathrm{bgl})$ to 1.910 to $12.200 \mathrm{~m} \mathrm{bgl}$ during pre-monsoon (2011) and in post-monsoon it ranges between 0.05-11.00 (m bgl) to 1.320 to $1355 \mathrm{~m} \mathrm{bgl}$ (CGWB (2013) respectively for Raichur and Koppal districts. Hence, stage of groundwater development in the study area is about 48.12 $\%$. Projected demand for domestic and industrial use up to 2025 is estimated about 42.44 to 60.48 ham respectively for Raichur and Koppal districts. Totally, groundwater draft is overdeveloped due to variations in the availability of precipitation and lack of perennial surface water bodies. Therefore, the development of groundwater assumes greater significance.

The traditional approach of groundwater investigation applying geological, hydrogeological and geophysical methods are costly due to high cost of drilling, time consuming and cumbersome for groundwater exploration on a regional scale (Ndatuwong and Yadav, 2014). Meanwhile, Remote Sensing (RS) and Geographic Information Systems (GIS) are useful in search of its prospect zones. As remote sensors cannot detect groundwater directly, its presence is inferred from different surface features derived from satellite imagery such as geology, landforms, soils, land use/ land cover, surface water bodies, etc., which act as indicators of groundwater existence (Todd, 1980 and Jha and Peiffer, 2006). RS and GIS have proved to be main tools to prepare those thematic maps from satellite images and it is also used as a multi-criteria decision analysis tool (Vittala et al., 2005; Madrucci et al., 2008; Mondal et al., 2008; Javed and Wani, 2009; Jha et al., 2010 and Dar et al., 2010).

\section{Materials and Methods}

\section{Description of study area}

Kanakanala Reservoir Subwatershed covered a maximum area from Koppal and minimum area from Raichur districts. This comes under D43E5 toposheet and located at $15^{\circ} 46^{\prime} 13.30^{\prime \prime}$ to $15^{\circ} 54^{\prime} 21.45^{\prime \prime}$ North latitude and $76^{\circ} 19^{\prime}$ $54.08^{\prime \prime}$ to $76^{\circ} 27^{\prime} 15.91^{\prime \prime}$ East longitude. It covers an average area of $195 \mathrm{~km}^{2}$ with an elevation of 500 feet. The major agricultural crops grown in the study area are Paddy, Jowar, Maize, Cotton, pulses and oil seeds. The study area is prevailed with subtropical climate with mild winters (December $=16.85$ 
${ }^{\circ} \mathrm{C}$ ) and hot summers (April $=45^{\circ} \mathrm{C}$ ). The average annual rainfall is $580-600 \mathrm{~mm}$ with the annual numbers of the rainy days 48 days. The location of the Kanakanala Reservoir Subwatershed is shown in the figure 1.

\section{Preparation of thematic layers}

Total six thematic layers were considered under study viz., slope, geology, geomorphology, soil, drainage density and Land use Land Cover (LULC) Map. The DEM was prepared (3D analyst tool in ArcGIS 10.1) from the contours which were digitized from the toposheet of the study area. Then the DEM was imported to Arc GIS 10.1 software to prepare slope map.

Geology, geomorphology and soil maps were extracted from the shape files which have been collected from the Karnataka State Remote Sensing Applications Centre, Bangalore, Karnataka. Drainage map was used to prepare the drainage density map by Spatial Analyst Tools in the Arc-GIS 10.1 software. Satellite Data Landsat Enhanced Thematic Mapper (ETM) data acquired on November, 2009 from that the Kanakanala Reservoir Subwatershed with an area of $195 \mathrm{~km}^{2}$ was extracted. Land use land cover map was prepared in ERDAS imagine by applying unsupervised classification.

\section{Delineation of groundwater potential zones by Weighted Index Overlay Analysis (WIOA)}

The groundwater potential zones of Kanakanala Reservoir Subwatershed were obtained by overlaying all the thematic maps in terms of weighted overlay method using the spatial analysis tool in ArcGIS 10.1 software. Weighted index overlay is applied where maps were added together in a weighted combination. This method is used in the present study because of its several advantages viz., it is frequently used models, easy and straightforward for a combined analysis of multiclass maps and also human judgment could be integrated with this analysis (Boobalan and Gurugnanam, 2016).

After understanding the behavior of geology, geomorphology, soil, slope, land use land cover and drainage density features with respect to groundwater control, the groundwater potential zones were delineated. Every thematic map was converted into raster format and gave weight. The rank of every thematic map was scaled by the weight of that theme (Arkoprovo et al., 2012). A weight (19) represents the virtual importance of a parameter and the objective (Boobalan and Gurugnanam, 2016) which was given by Multi Influencing Factor (MIF). There is no standard scale for simple weighted overlay methods, for this purpose, criteria for the analysis are defined and each parameter was given its due importance (Saraf and Choudhury, 1998; Chaturvedi et al., 1983; Raj and Sinha, 1989; Baldev et al., 1991; Gustafsson, 1993; Krishnamurthy and Srinivas, 1995; Saraf et al., 1997; 1998; Shahid et al., 2000; Jasrotia et al., 2007a; Jasrotia et al., 2012b; Mandal, 2011; Sedhuraman et al., 2014 etc). The weights and rank have been given by considering the works carried out by Krishnamurthy et al., (1996), Dey (2014) and Waikar and Nilawar (2014). The weight assigned to different classes of all the thematic layers are given in table 1. In this simplest type of weighted model, input maps are binary and each map carries a single weight factor (Jhariya et al., 2015). The representative weight of a factor of the potential zone is the sum of all weights from each factor. A factor with a higher weight value shows a larger impact and a factor with a lower weight value shows a smaller impact on groundwater potential zones (Magesh et al., 2012). Moreover, these factors are interdependent. While assigning the weight, geology and 
geomorphology were assigned higher weight and slope and drainage density were assigned lower weight.

In order to get all information unified, it is necessary to integrate data with proper factor and it is also possible to superimpose this information manually (Horton, 1945). After assigning weights groundwater potential zones were obtained by overlaying all the thematic maps in terms of weighted overlay method using the spatial analysis tool in ArcGIS 10.1 software.

\section{Results and Discussion}

\section{Digital Elevation Model (DEM) and slope map}

Topography (land surface elevation) is one of the factors which influence groundwater potential. Higher the elevation, lesser would be the groundwater availability (Sener et al., 2005). A digital elevation model (DEM) is a digital representation of ground surface topography of terrain. It indicates a digital explanation of the terrain relief and it could be stored in different forms such as contour lines, raster based array of cells and Triangulated Interface Network (TIN). The Digital Elevation Model (DEM) prepared for Kanakanala Reservoir Subwatershed is shown in figure 2 which shows the highest elevation of $624 \mathrm{~m}$ and lowest elevation of $500 \mathrm{~m}$.

The slope of a surface refers to the maximum rate of change in height across a region of the surface and is main terrain parameter to influence the land stability (Manjare, 2014). Slope of terrain is one of the main factor governing the infiltration of groundwater into subsurface makes it a suitable groundwater indicator (Sikakwe et al., 2015). The surface runoff is slow allowing in the gentle slope area so that it takes more time for rainwater to percolate, whereas, steep slope area facilitates high runoff so which allows less residence time for rainwater and hence somewhat less infiltration (Sitender and Rajeshwari, 2011).

The slope percentage in the study area varied from 0 to 40 percent and it was divided into seven classes. Most of the area $\left(96.12 \mathrm{~km}^{2}\right)$ was covered by 0-1 percent slope (nearly level) which exhibits good groundwater potential because of less runoff. About 64.16 $\mathrm{km}^{2}$ area was considered under good groundwater occurrence because of the very gently slope category (1-3 percent). An area of $21.97 \mathrm{~km}^{2}$ with 3-6 percent (gently sloping) was assumed to exhibit moderate potential for groundwater. An area of $2.60 \mathrm{~km}^{2}, 2.56 \mathrm{~km}^{2}$, $5.40 \mathrm{~km}^{2}$ and $2.19 \mathrm{~km}^{2}$ with slope of $6-9$ percent (moderately sloping), 9-13 and 13-21 percent (moderately steep sloping) and 21-40 percent (steep) respectively were considered as poor and very poor classification for groundwater potential. Here, the lower slope values indicate the flatter terrain (gentle slope) and higher slope values correspond to steeper slope of the terrain. It gives an idea that lands having lesser slope are useful for groundwater recharge where as steep slopes are unfit for the recharge of groundwater. Figure 3 shows the slope map of the Kanakanala Reservoir Subwatershed.

\section{Geology}

It is one of the most important factor which plays significant role in the distribution and occurrence of groundwater (Ramu et al., 2014). The storage capability of the rock formations depends on porosity of the rock. In the rock formation the water moves from areas of recharge to areas of discharge under the influence of hydraulic gradients depending on the permeability or hydraulic conductivity (Manikandan et al., 2014). Figure 4 shows the geological map of the Kanakanala Reservoir Subwatershed. It is helpful to study the aquifer characteristics like aquifer thickness, type of 
aquifer, porosity, permeability etc. and also for selecting site for construction of check dam, ponds etc., (Radhakrishnan and Ramamoorthy, 2014).

Phyllite quartz chlorite schist and greywalke and metavolcanics covers large amount of area of $78.98 \mathrm{~km}^{2}$ and $61.07 \mathrm{~km}^{2}$ respectively and are considered as moderate for groundwater potential. Migmatites and granodiorite tonalitic gneiss occupied $39.19 \mathrm{~km}^{2}$ area which was also moderate for groundwater potential. Granodiorite and granite and grey / pink granite covered $13.60 \mathrm{~km}^{2}$ and $2.16 \mathrm{k} \mathrm{m}^{2}$ area and exhibits very poor and poor potential for groundwater occurrence respectively. The weightage were assigned based on the rock's influence in the groundwater potential.

\section{Geomorphology}

Geomorphological studies is one of the most significant aspects in the assessment of water resources both surface and groundwater. Geomorphological mapping involves the recognition and categorization of various landforms and structural features, which are favorable for the occurrence of groundwater (Sitender and Rajeshwari, 2011). An integrated study of the evolution of landforms and geology is useful to recognize the occurrence of permeable and porous zones (Karanth, 1987). For the assessment of groundwater resources, a geomorphological terrain classification leading to the delineation of hydro-morphological is helpful by taking both morphological and lithological factors into consideration (Verstappen, 1983). The study of geomorphology plays a considerable control over the groundwater region, slope, relief, depth of weathering, nature of the deposited materials, thickness of deposition and the assemblage of different landforms (Radhakrishnan and Ramamoorthy, 2014). The geomorphic units identified in the study area include pediment-inselberg complex, pediplain weathered/buried, structural hills (small) and water body which are shown in figure 5. Maximum extent of area is covered by pediplain weathered/buried about 154.08 $\mathrm{km}^{2}(79.01 \%)$ and included under moderate to good for groundwater potential. Pediment Inselberg Complex (PI) occupied an area of $34.52 \mathrm{~km}^{2}(17.70 \%)$ and considered as moderate to good for groundwater potential. Structural Hills $(\mathrm{SH})$ and water bodies were occupied $1.62 \mathrm{~km}^{2}(0.83 \%)$ and $4.78 \mathrm{~km}^{2}$ $(2.46 \%)$ respectively and considered under moderate to good zone for groundwater potential.

\section{Soil map}

Soil is one of the natural resources, which is an important parameter to delineate potential groundwater zones and it plays a vital role in groundwater recharge and encounters the basic requirements of all agricultural production (Radhakrishnan and Ramamoorthy, 2014). Soil features invariably control penetration of surface water into groundwater system and they are directly related to rates of infiltration, percolation and permeability (Sedhuraman et al., 2014) and those affects the water holding and infiltrating capacity of a soil. Soil moisture and permeability is an indicator of potential zone (Jose et al., 2012).

It is apparent from figure 6 that the majority of the study area is dominated by clay and loam soils with an area of coverage $68.71 \mathrm{~km}^{2}$ $(35.23 \%)$ and $63.52 \mathrm{~km}^{2} \quad(32.57 \%)$ respectively. Similarly, sandy loam, loamy clay, clayey loam, water body, sandy clay, loamy sand and habitation covered an area of $32.16 \mathrm{~km}^{2}$ (16.49\%), $17.47 \mathrm{~km}^{2}(8.96 \%), 4.82$ $\mathrm{km}^{2}(2.47 \%), 4.81 \mathrm{~km}^{2}(2.46 \%), 1.91 \mathrm{~km}^{2}$ $(0.98 \%), 0.84 \mathrm{~km}^{2}(0.43 \%)$ and $0.80 \mathrm{~km}^{2}$ $(0.41 \%)$ respectively. 
Table.1 Weights and percentage influence considered for parameters of Groundwater potential zones

\begin{tabular}{|c|c|c|c|c|}
\hline Theme & Sub-Classes & Category & Weight & $\begin{array}{l}\text { Influence } \\
\text { (weight) \% }\end{array}$ \\
\hline \multirow[b]{5}{*}{ Geology } & Granodiorite and granite & Very poor & 1 & \multirow{5}{*}{$(m-8)$} \\
\hline & Grey / pink granite & Poor & 2 & \\
\hline & Phyllite quartz chlorite schist and greywalke & Moderate & 3 & \\
\hline & Metavolcanics & Moderate & 3 & \\
\hline & Migmatites and granodiorite - tonalitic gneiss & Moderate & 3 & \\
\hline \multirow[b]{4}{*}{ Geomorphology } & Pediplain weathered/buried & Moderate to good & 6 & \multirow[b]{4}{*}{25} \\
\hline & Pediment Inselberg Complex (PI) & Moderate to good & 5 & \\
\hline & Structural Hills (SH) & Moderate & 3 & \\
\hline & Water body & Good & 8 & \\
\hline \multirow[b]{9}{*}{ Soils } & Sandy loam & Very good & 9 & \multirow[b]{9}{*}{15} \\
\hline & Sandy clay & Good & 7 & \\
\hline & Loamy sand & Good & 8 & \\
\hline & Loam & Moderate to good & 6 & \\
\hline & Loamy clay & Moderate & 4 & \\
\hline & Clayey loam & Moderate & 4 & \\
\hline & Clay & Very poor & 1 & \\
\hline & Habitation & Very poor & 1 & \\
\hline & Water body & Very good & 9 & \\
\hline \multirow[b]{6}{*}{ Land use land cover } & Agriculture & Moderate to good & 6 & \multirow[b]{6}{*}{15} \\
\hline & Water body & Moderate to good & 6 & \\
\hline & Barren land & Moderate to good & 5 & \\
\hline & Scrubland & Moderate & 3 & \\
\hline & Rocky outcrop & Very poor & 1 & \\
\hline & Settlements & Very poor & 1 & \\
\hline \multirow[b]{7}{*}{ Slope } & $0-1 \%$ & Very good & 8 & \multirow[b]{7}{*}{10} \\
\hline & $1-3 \%$ & Good & 7 & \\
\hline & $3-6 \%$ & Good & 6 & \\
\hline & $6-9 \%$ & Moderate & 4 & \\
\hline & $9-13 \%$ & Moderate & 3 & \\
\hline & $13-21 \%$ & Poor & 2 & \\
\hline & $21-40 \%$ & Very poor & 1 & \\
\hline \multirow{5}{*}{$\begin{array}{l}\text { Drainage density } \\
(\mathbf{K m} / \mathbf{K m} 2)\end{array}$} & $0-0.25$ & Moderate & 5 & \multirow[b]{5}{*}{10} \\
\hline & $0.26-0.510$ & Moderate & 4 & \\
\hline & $0.52-0.90$ & Moderate & 4 & \\
\hline & $0.91-1.42$ & Moderate & 3 & \\
\hline & $1.43-2.59$ & Very poor & 1 & \\
\hline
\end{tabular}


Fig.1 Location map of the Kanakanala reservoir subwatershed, Karnataka

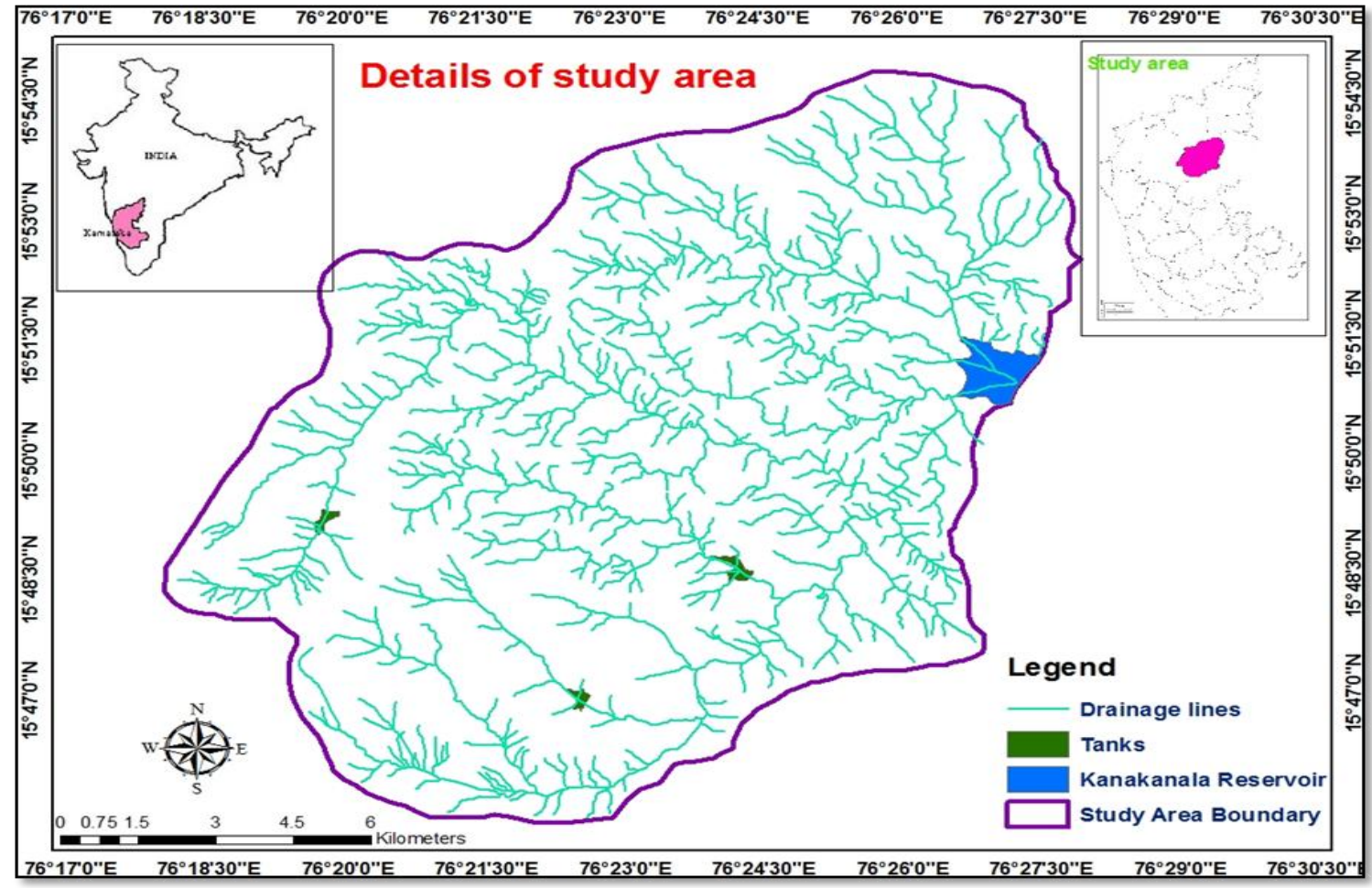

Fig.2 DEM of the Kanakanala reservoir subwatershed

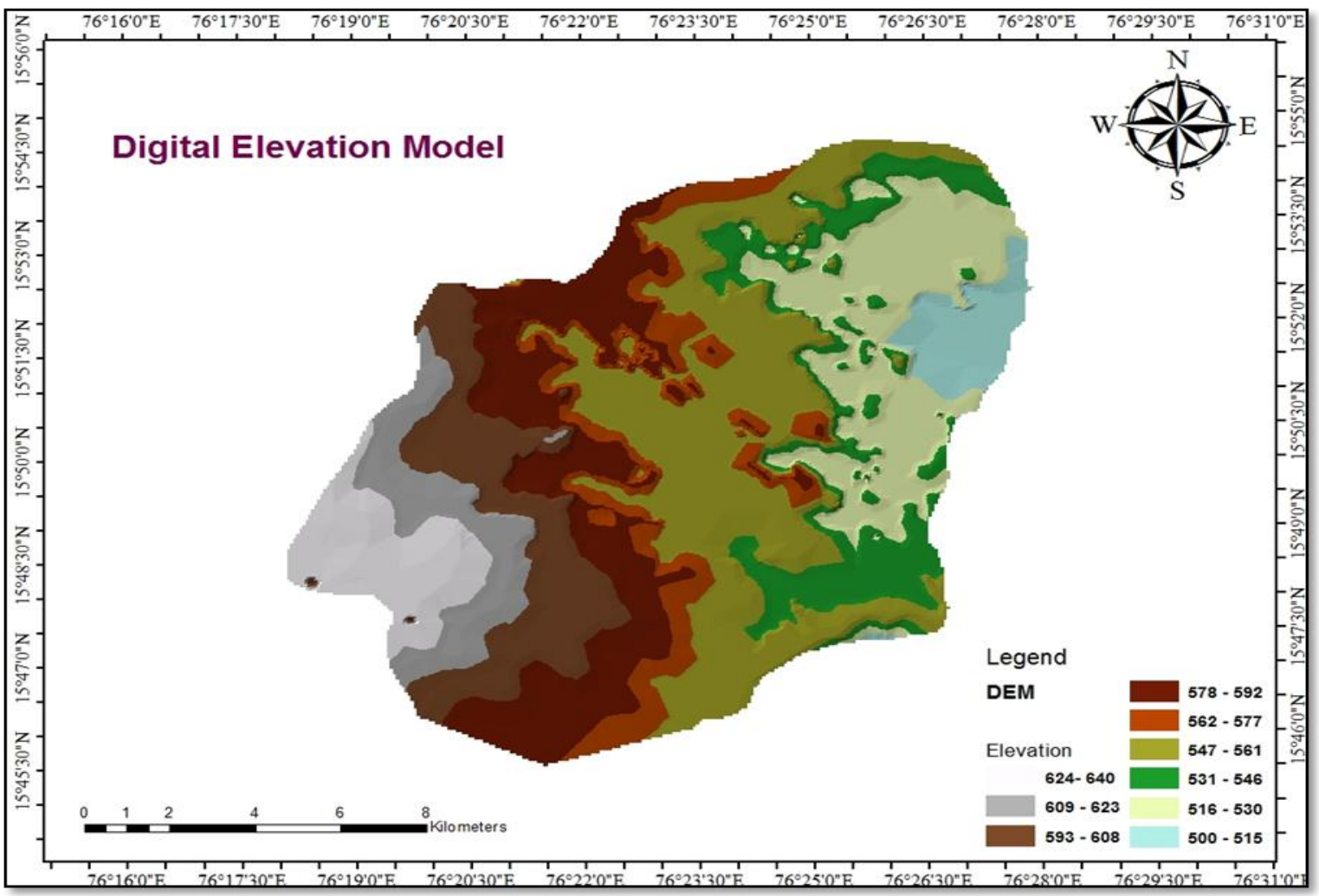


Fig.3 Slope map of the Kanakanala reservoir subwatershed

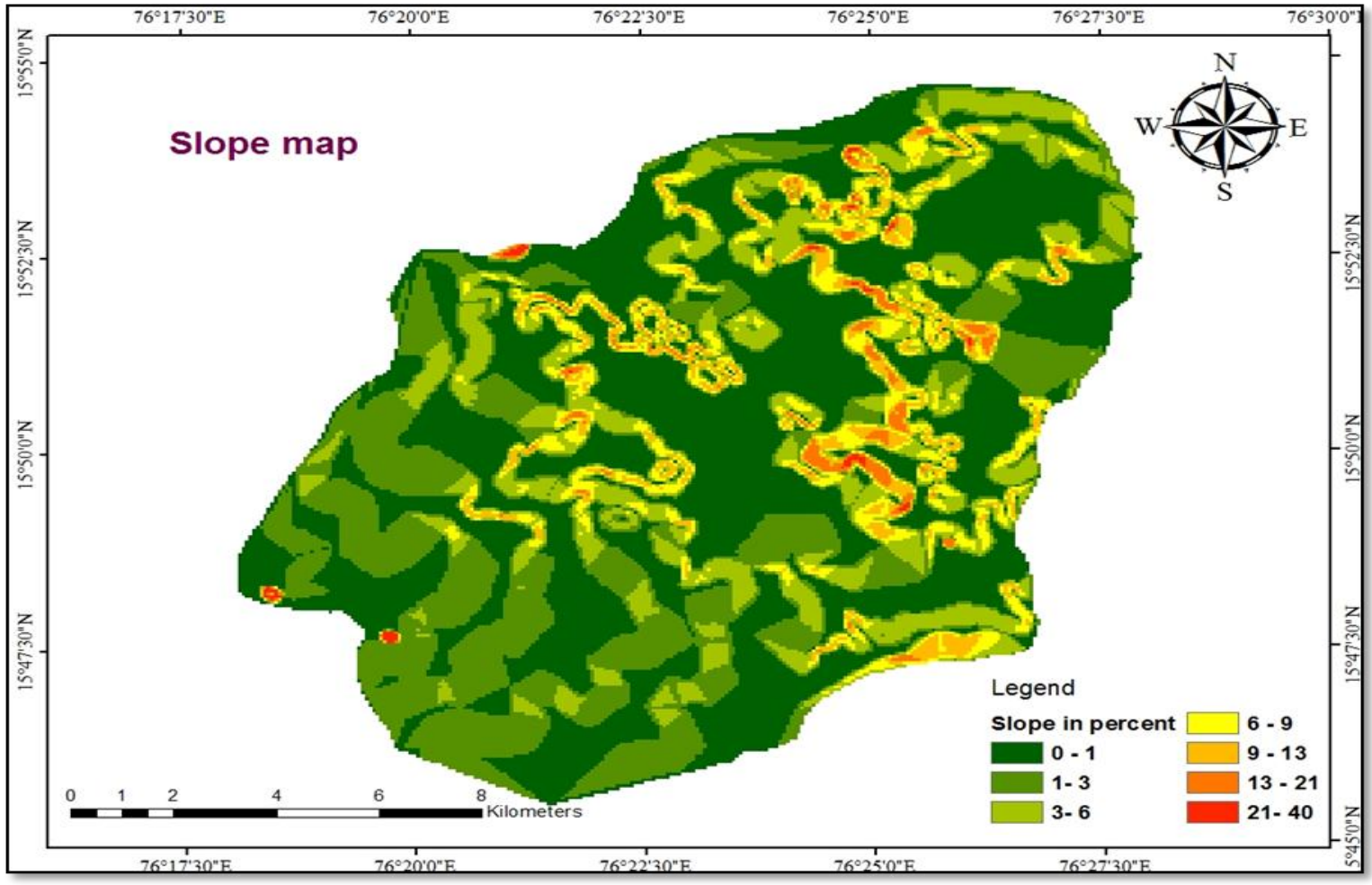

Fig.4 Geological map of the Kanakanala Reservoir Subwatershed

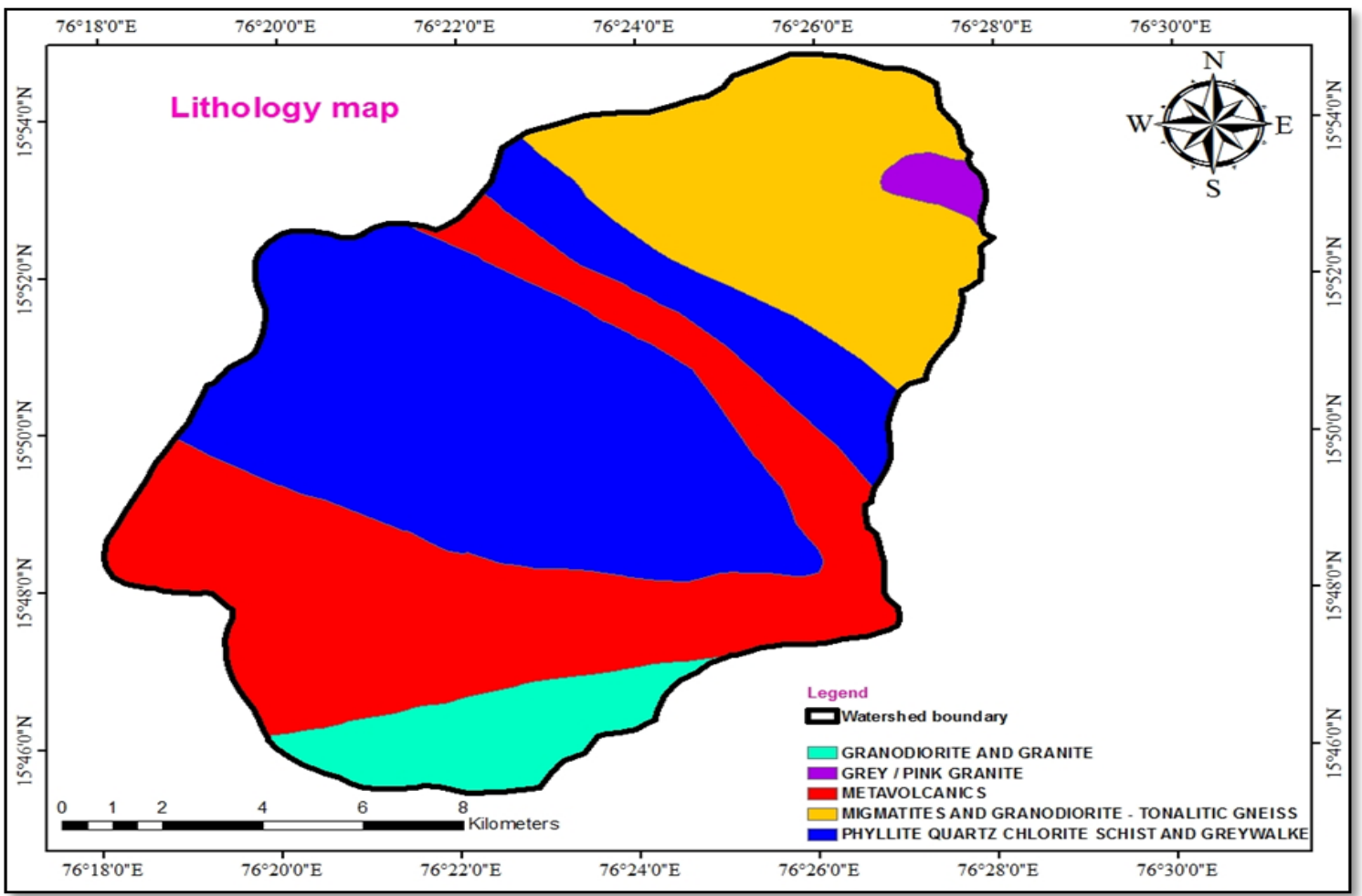


Fig.5 Geomorphological map of the Kanakanala reservoir subwatershed

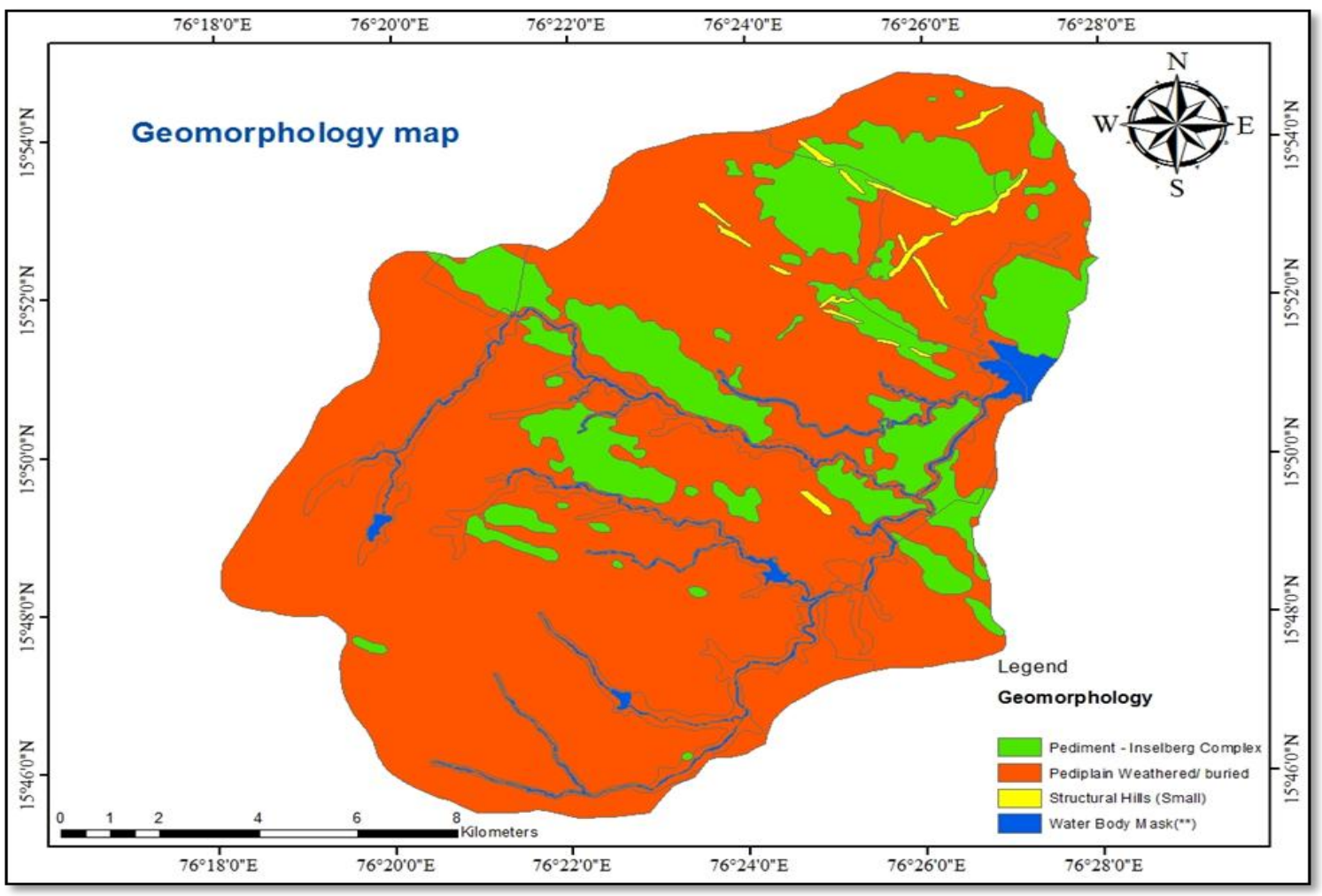

Fig.6 Soil map of the Kanakanala reservoir subwatershed

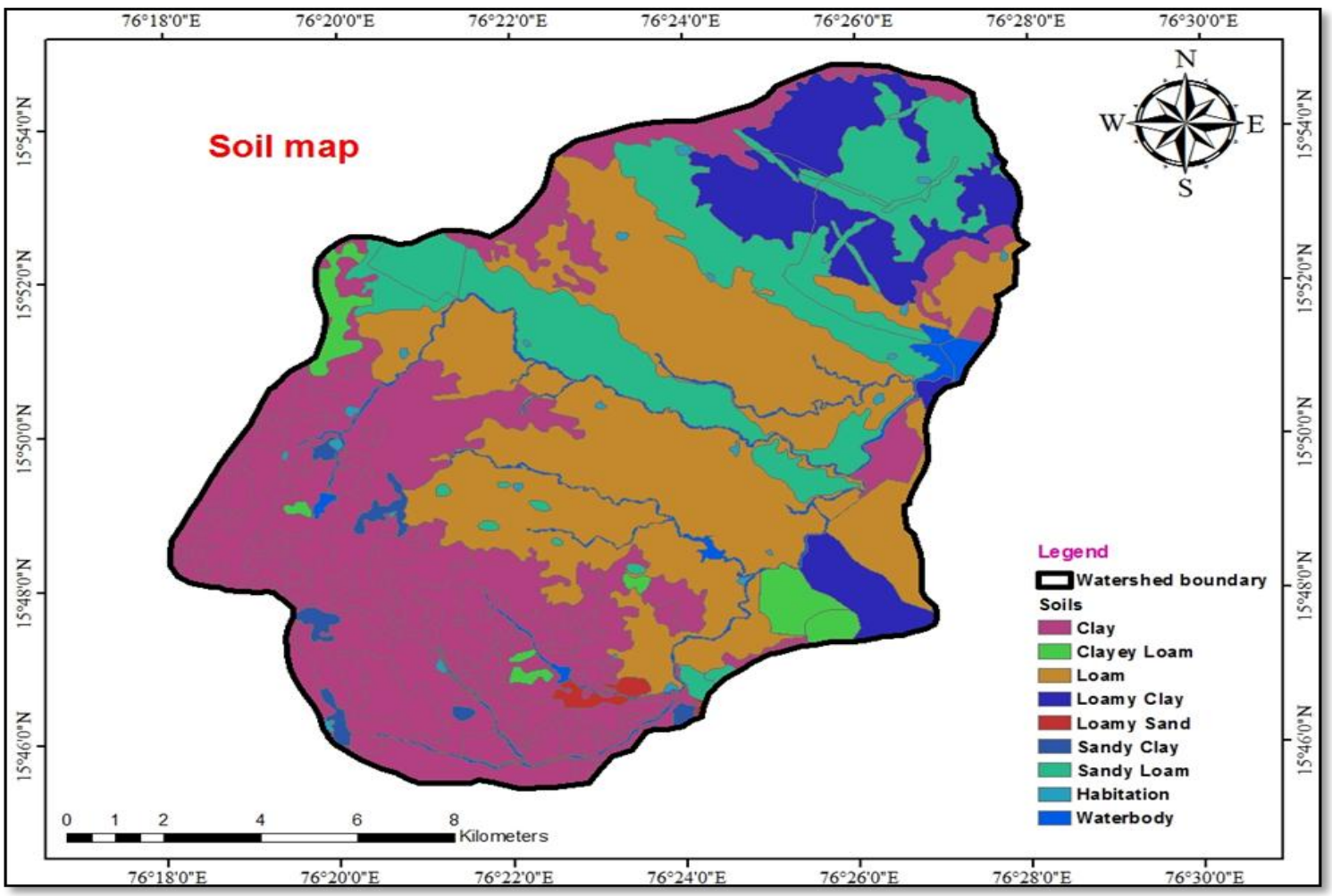


Fig.7 Drainage density map of the Kanakanala reservoir subwatershed

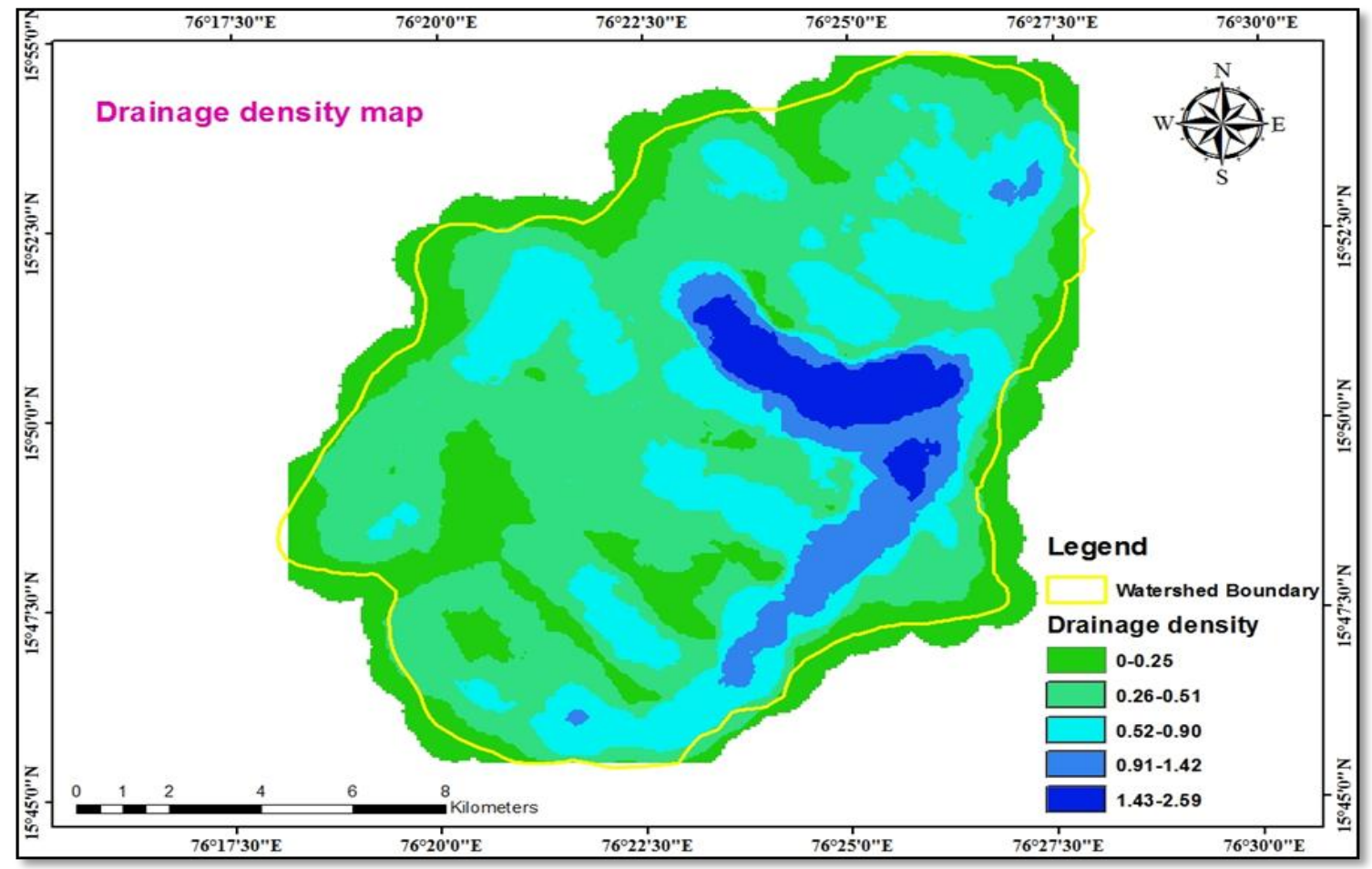

Fig.8 Land use/land cover map of the Kanakanala reservoir subwatershed

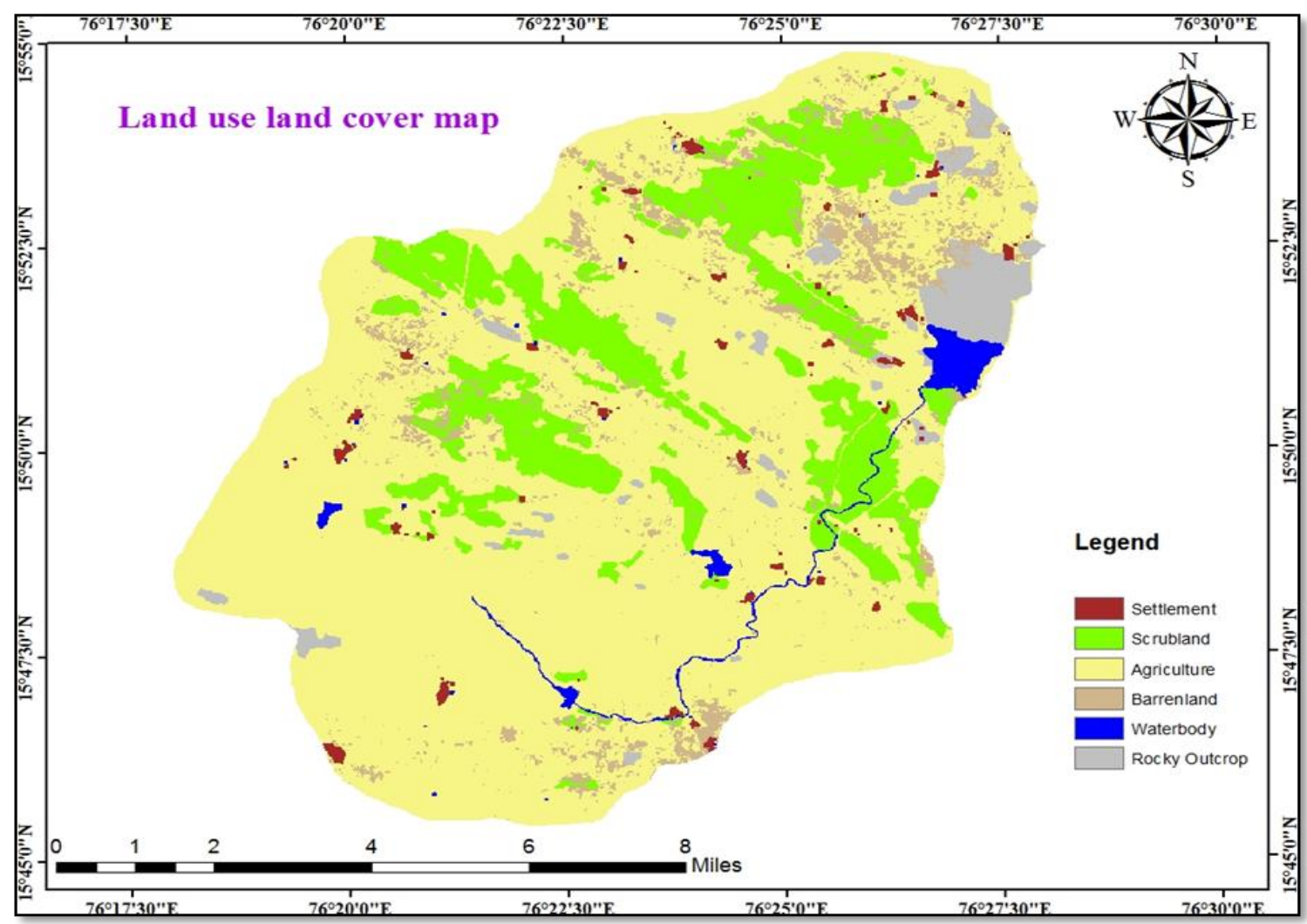


Fig.9 Groundwater potential zones of Kanakanala reservoir subwatershed

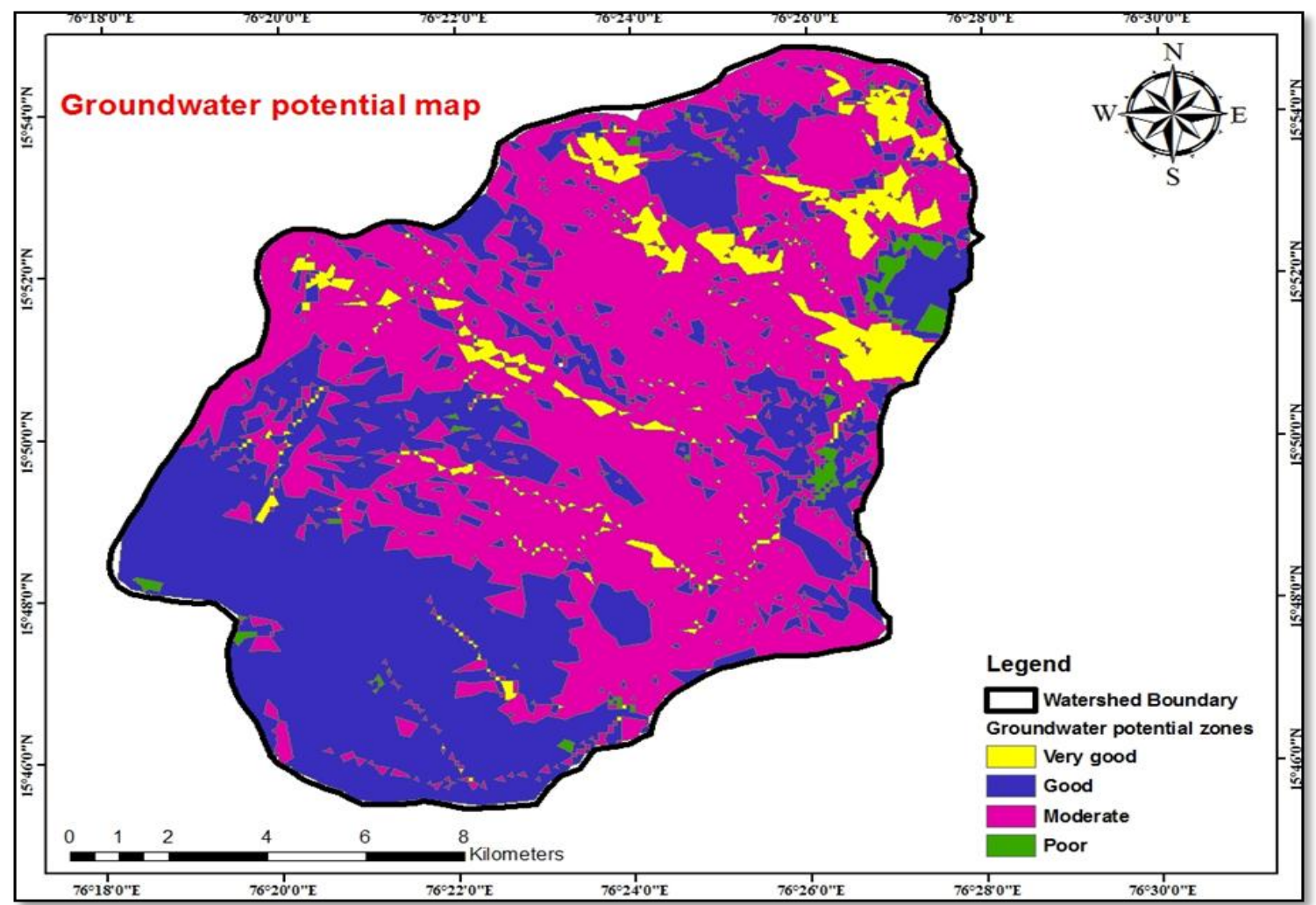

Clay soils show poor potential for groundwater and clayey loam and loamy clay are considered to exhibit moderate for groundwater potential. Loam and sandy loam soils were categorized under moderate to good and good potential for groundwater respectively. Sandy clay and loamy sands were considered to show good condition for groundwater occurrence.

\section{Drainage density}

Drainage density is defined as the closeness of spacing of stream networks because of its relation with surface runoff and permeability (Magesh et al., 2012). It is an inverse function of permeability. Sub-surface hydrological condition of any area is controlled by the drainage characteristics of the basin that leads to decipher the groundwater condition. The drainage density could indirectly point out the groundwater potential of an area due to its relation to surface runoff and permeability (Pradhan, 2009). If there is less permeable rock, the infiltration of rainfall would be less, which conversely tends to be concentrated in surface run-off (Hutti and Nijagunappa, 2011).

Low drainage density generally found in the areas of highly resistant or permeable subsoil material, low relief and dense vegetation, similarly high drainage density is found in the areas of sparse vegetation, weak or impermeable subsurface material and mountainous relief (Choudhari et al., 2014). Normally, groundwater potential is found to be poor in very high drainage density areas because of the main part of the water poured over them during rainfall is lost as surface runoff with small infiltration to meet groundwater (Sitender and Rajeshwari, 2011). On the contrary areas of low drainage density permit more infiltration and recharge to the 
groundwater so that they have more potential for groundwater occurrence (Sitender and Rajeshwari, 2011).

Low drainage density leads to coarse drainage texture while high drainage density leads to fine drainage texture (Choudhari et al., 2014), so that, the Kanakanala Reservoir Subwatershed was occupied by coarse drainage texture at maximum areal extent $\left(130 \mathrm{~km}^{2}\right)$ and remaining area of $65 \mathrm{~km}^{2}$ was covered by fine drainage texture.

The drainage density map of the Kanakanala Reservoir Subwatershed is shown in figure 7. The drainage density was classified in to five types, very low $\left(0-0.25 \mathrm{~km}^{2}\right)$, low $(0.26-0.51$ $\left.\mathrm{km}^{2}\right)$, moderate $\left(0.52-0.90 \mathrm{~km}^{2}\right)$, high $(0.91-$ $\left.1.42 \mathrm{~km}^{2}\right)$ and very high densities (1.43-2.59 $\mathrm{km}^{2}$ ) (Patil and Mohite, 2014). The maximum area of the Kanakanala Reservoir Subwatershed occupied by low drainage density with an area of $80.71 \mathrm{~km}^{2}(41.39 \%)$ followed by very low and moderate drainage density with an area of $49.38 \mathrm{~km}^{2}(25.32 \%)$ and $45.07 \mathrm{~km}^{2}(23.11 \%)$ respectively. Remaining area is covered by high, $12.02 \mathrm{~km}^{2}$ $(6.16 \%)$ and very high $7.82 \mathrm{~km}^{2}(4.02 \%)$ drainage densities respectively. Accordingly groundwater potential was considered as moderate and very poor zones respectively.

\section{Land use/land cover map}

The term land cover narrates to the type of characteristic present on the surface of the earth whereas land use refers to the human activity relates with the specific piece of land (Lillesand and Kiefer, 1979). Land use/land cover mapping is one of the significant applications of remote sensing as it plays a considerable role in the development of groundwater resources (Waikar and Nilawar, 2014). It controls many hydro-geological processes in the water cycle viz., evapotranspiration, infiltration, surface runoff etc., (Waikar and Nilawar, 2014). Surface cover provides roughness to the surface thereby reduces discharge and increases the infiltration. In the forest areas, infiltration would be more because of less runoff whereas in urban areas rate of infiltration might decrease (Waikar and Nilawar, 2014). It is one of the chief parameter for the geohydrological study because the land use pattern of any terrain is an indication of the complex physical processes acting upon the surface of the earth (Arivalagan et al., 2014).

Land use land cover classes control the occurrence of groundwater and also causes for infiltration for recharge, with various classes among itself. The effect of land use land cover is manifested either by reducing runoff and facilitating or by trapping water on their leaf (Patil and Mohite, 2014). The land use/land cover of the study area is characterized by a mixture of agriculture, scrubland, barren land, rocky outcrop, water body and settlements which is shown in figure 8. Agriculture covered maximum extent of the Kanakanala Reservoir Subwatershed about $139.28 \mathrm{~km}^{2}$ (71.43\%). Similarly, scrubland, barren land, rocky outcrop, water body and settlements covered $32.12 \mathrm{~km}^{2}$ (16.47\%), $11.66 \mathrm{~km}^{2}$ (5.98\%), $7.19 \mathrm{~km}^{2}(3.68 \%), 2.77$ $\mathrm{km}^{2}(1.41 \%)$ and $1.97 \mathrm{~km}^{2} \quad(1.01 \%)$ respectively.

Agriculture, water body and barren lands are considered to exhibits moderate to good groundwater potential. Meanwhile, scrubland, rocky outcrop and settlement showed moderate and very poor potential of groundwater occurrence respectively.

\section{Groundwater potential zoning}

The thematic maps of geology, geomorphology, soil, slope, land use/land cover and soil were considered for identifying groundwater potential zones in the 
Kanakanala Reservoir Subwatershed. Totally four groundwater potential zones are classified as very good, good, moderate and poor which is shown in the figure 9. Most of the area covered by moderate potential zones with an aerial extent of $98.97 \mathrm{~km}^{2}(50.74 \%)$ followed by good groundwater zones with an area of $80.88 \mathrm{~km}^{2}$ (41.47\%). Remaining area was categorized as very good and good potential zones with an aerial extent of about $12.85 \mathrm{~km}^{2}(6.59 \%)$ and $2.35 \mathrm{~km}^{2}(1.21 \%)$ respectively.

Weighted Index Overlay Analysis (WIOA) approach for assessment of groundwater potential was adopted and potential zones were demarcated. From the study it is noticed that the groundwater occurrence is moderate to good in condition in the Kanakanala Reservoir Subwatershed. Thus it is suggested that, for further improvement of groundwater condition, it is necessary to construct check dams, percolation tanks, form ponds and other water harvesting structures. From the study it was observed that RS and GIS technique could be used effectively in delineation of groundwater potential zones. Also it was found efficient to minimize the labor, time and money so that it enables quick decision making for sustainable water resource management. From the study it was concluded that, for any implementation of groundwater management system and watershed conservation strategies, identification of groundwater potential zones plays a key role.

\section{Acknowledgement}

Author is thankful to Mr. Sham Davande, GIS Analyst, FES, Anand, Gujarat, for his guidelines in the preparation of thematic maps in ArcGIS software. Also thankful to Dr. H. K. Mittal and Dr. U. Satishkumar for their useful suggestions in completing the project.

\section{References}

Arivalagan, S., A. M. Kiruthika and Sureshbabu, S. 2014. Delineation of groundwater potential zones using RS and GIS techniques: a case study for Eastern part of Krishnagiri district, Tamil Nadu. International Journal of Advance Research in Science and Engineering. 3(3):51-59.

Arkoprovo, B., J. Adarsa and Prakash, S. S. 2012. Delineation of groundwater potential zones using satellite remote sensing and geographic information system techniques: A case study from Ganjam district, Orissa, India. Research Journal of Recent Sciences. 1(9):59-66.

Baldev, S., A. Bhattacharya and Hegde, V. S. 1991. IRS-1A application for groundwater targeting. Current Science. 61:172-179.

Boobalan, C., and Gurugnanam, B. 2016. Mapping of groundwater potential zones in Sarabanga Sub-basin, Cauvery River, South India, Using remote sensing and GIS techniques. Indian Journal of Applied Research. 6(2):364-369.

CGWB. 2013. Groundwater information booklet Koppal district, Karnataka, Government of India, Ministry of Water Resources, Central Ground Water Board.

CGWB. 2013. Groundwater information booklet Raichur district, Karnataka, Government of India. Ministry of Water Resources, Central Ground Water Board.

Chaturvedi, R. S., D. C. Bhattacharya, P. Kamal, J. Krishnamurthy and Sunder, R. N. 1983. Integrating Remote Sensing techniques in groundwater exploration - a typical case study from Bundelkhand region in Uttar Pradesh. In Proceedings of National Symposium on Remote Sensing in Development and Management of Water Resources, Ahmedabad. 25-27 October 1983.

Chaudhary, B. S., A. K. ManojKumar, Roy and Ruhal, D. S. 1996. Application of Remote Sensing and Geographic Information 
Systems in groundwater investigations in Sohna Block, Gurgaon District, Haryana, India. International Archives of Photogrammetry and Remote Sensing. XXXI (B6): 18-23.

Choudhari, K., B. Panigrahi and Paul, J. C. 2014. Morphometric analysis of Kharlikani watershed in Odisha, India using spatial information technology. International Journal of Geomatics and Geosciences. 4(4):661-671.

Dar, M. A., K. Sankar and Dar, I. A. 2010. Groundwater prospects evaluation based on hydro-geomorphological mapping: a case study in Kancheepuram district, Tamil Nadu. Journal of Indian Society of Remote Sensing. 38(2):333-343.

Dey, S., 2014. Delineation of groundwater prospect zones using Remote Sensing, GIS Techniques - A case study of Baghmundi Development Block of Puruliya District, West Bengal. International Journal of Geology, Earth and Environmental Sciences. 4(2):62-72.

Gustafsson, P., 1993. High-resolution satellite data and GIS as a tool for assessment of groundwater potential of a semi-arid area. In IX Thematic conference on Geologic Remote Sensing, Pasadena. California. $P_{P} .8-11$.

Horton, R. E., 1945. Erosional development of streams and their drainage basins; hydrophysical approach to quantitative morphology. Geological society of America bulletin. 56(3):275-370.

Hutti, B., and Nijagunappa, R. 2011. Identification of groundwater potential zone using geoinformatics in Ghataprabha basin, North Karnataka, India. International Journal of Geomatics and Geosciences. 2(1):91-109.

Jasrotia, A. S., A. Kumar and Aasim, M. 2012b. Morphometric analysis and hydrogeomorphology for delineating groundwater potential zones of Western Doon Valley, Uttarakhand, India. International Journal of Geomatics and Geosciences. 2(4):1078-1096.

Jasrotia, A. S., Kumar, R and Saraf, A. K. 2007a. Delineation of groundwater recharge sites using integrated Remote Sensing and GIS in Jammu District, India. International Journal of Remote Sensing. 28(22):5019-5036.

Javed, A., and Wani, M. H. 2009. Delineation of groundwater potential zones in Kakund Watershed, Eastern Rajasthan, using Remote Sensing and GIS techniques. Journal of Geological Society of India. 73(2):229-236.

Jha, M. K., and Peiffer, S. 2006. Applications of Remote Sensing and GIS Technologies in Groundwater Hydrology: Past, Present and Future (Bayreuth, Germany: BayCEER). $\mathrm{P}_{\mathrm{P}} .201$.

Jha, M. K., V. M. Chowdary and Chowdhury, A. 2010. Groundwater assessment in Salboni Block, West Bengal (India) using Remote Sensing, Geographical Information System and multi-criteria decision analysis techniques. Hydrogeology Journal. 18(7):1713-1728.

Jhariya, D. C., S. Swati, S. K. Nage and Chatterjee, R. S. 2015. Integrated Remote Sensing and GIS approach to groundwater potential delineation in the Doon Valley, Uttarakhand, India. International Journal of Geo Science and Geo Informatics. 2(1):1-12.

Jose, S. K., R. R. Jayasree, Santhosh Kumar and Rajendran, S. 2012. Identification of groundwater potential zones in Palakkad District, Kerala through multicriteria analysis techniques using geoinformation technology. Bonfring International Journal of Industrial Engineering and Management Science. 2(1):62-68.

Karanth, K. R., and Seshu babu, K. 1987. Identification of major lineaments on satellite imagery and on aerial photographs for delineation for possible potential groundwater zones in Penukonda and Dharmavaram taluks of Anantapur district. In: Proceedings of Joint Indo-US Workshop on Remote Sensing of Water Resources (NRSA, Hyderabad), 188-197. Indian Society of Remote Sensing (ISRS) National Natural 
Resources Management System (NNRMS), Ahmedabad, India.

Krishnamurthy, J., G. Srinivas, V. Jayaram and Chandrasekhar, M. G. 1996. Influence of rock type and structure in the development of drainage networks in typical hard rock terrain. Information Technology and Control Journal. 3(4):252-259.

Krishnamurthy, J., and Srinivas, G. 1995. Role of geological and geomorphological factors in groundwater exploration: a study using IRS LISS data. International Journal of Remote Sensing. 16(14):25952618.

Lillesand, T. M., and Kiefer, R. W. (1979). Remote Sensing and image interpretation. John Willey and Sons, Ins.

Madrucci, V., F. Taioli and deArau'jo, C. C. 2008. Groundwater favorability map using GIS multicriteria data analysis on crystalline terrain, Sao Paulo State, Brazil. Journal of Hydrology. 357(3 4):153-173.

Magesh, N. S., N. Chandrasekar and Soundranayagam, J. P. 2012. Delineation of groundwater potential zones in Theni district, Tamil Nadu, using remote sensing, GIS and MIF techniques. Geoscience Frontiers. 3(2):189-196.

Mandal, D. K., 2011. Identification of groundwater potential zone in and around Dehra Doon using index overlay method. India Cartographer. 31(1):190-196.

Manikandan. J., A. M. Kiruthika and Sureshbabu, S. 2014. Evaluation of groundwater potential zones in Krishnagiri District, Tamil Nadu using MIF Technique.

Manjare, B. S., 2014. Identification of groundwater prospecting zones using Remote Sensing and GIS techniques in Upper Vena River Watersheds Nagpur District, Maharashtra, India. In 15th ESRI India User Conference. $\mathrm{P}_{\mathrm{P}}$ 1-14.

Mondal, M. S., A. C. Pandey and Garg, R. D. 2008. Groundwater prospects evaluation based on hydro-geomorphological mapping using high resolution satellite images: a case study in Uttarakhand. Journal of Indian Society of Remote Sensing. 36(1):69-76.

Ndatuwong, L. G., and Yadav, G. S. (2014). Morphometric analysis to infer the hydrogeological behavior in part of Sonebhadra District, Uttar Pradesh, India, using Remote Sensing and GIS Technique. International Journal of Remote Sensing and GIS. 3(1):1-7.

Patil, S. G., and Mohite, N. M. 2014. Identification of groundwater recharge potential zones for a watershed using remote sensing and GIS. International Journal of Geomatics and Geosciences. 4(3):485-498.

Pradhan, B., 2009. Groundwater potential zonation for basaltic watersheds using satellite remote sensing data and GIS techniques. Central European Journal of Geosciences. 1(1): 120-129.

Radhakrishnan, D., and Ramamoorthy. P. 2014. Delineation of groundwater recharge potential zones in Mailam Block, Villupuram district, Using GIS. International Journal of Water Research. 2(2):71-75.

Raj, S., and Sinha, A. K. 1989. An integral approach for the delineation of potential groundwater zones using satellite data: case study, Udaipur district, Rajasthan. Journal of Asia-Pacific Remote Sensing. 2:61-64.

Ramu., B. Mahalingam and Vinay, M. 2014. Identification of groundwater potential zones using GIS and Remote Sensing Techniques: A case study of Mysore Taluk-Karnataka. International Journal of Geomatics and Geosciences. 5(3):393403.

Saraf, A. K., and Choudhury, P. R. 1998. Integrated Remote Sensing and GIS for groundwater exploration and identification of artificial recharge sites. International Journal of Remote Sensing. 19(10):1825-1841.

Saraf, A. K., and Jain, S. K. 1997. Integrated use of Remote Sensing and Geographical Information System methods for 
groundwater exploration in parts of Lalitpur district, UP. In: International Conference on Hydrology and Water Resources (New Delhi, 20-22 December 1993) Kluwer Academic Publishers, Dordrecht, The Netherlands.

Sedhuraman, M., S. S. Revathy and Suresh, B. S. 2014. Integration of geology and geomorphology for groundwater assessment using Remote Sensing and GIS techniques. International Journal of Innovative Research in Science, Engineering and Technology. 3(3):1020310211.

Sener, E., A. Davraz and Ozcelik, M. 2005. An integration of GIS and remote sensing in groundwater investigation: A case study in Burdur, Turkey. Hydrogeology Journal. 13(5-6):826-834.

Shahid, S., S. K. Nath and Roy, J. 2000. Groundwater potential modeling in a soft rock area using a GIS. International Journal of Remote Sensing. 21:1919 1924.

Sikakwe, G. U., E. E. U. Ntekim, D. A. Obi and George, A. M. 2015. Geo-hydrological study of weathered basement aquifers in Oban Massif and environs Southeastern Nigeria: using Remote Sensing and Geographic Information System Techniques. Journal of Applied Geology and Geophysics. 3(2): 27-40.

Sitender, and Rajeshwari. 2011. Delineation of groundwater potential zones in Mewat District, Haryana, India. International Journal of Geomatics and Geosciences. 2(1):270- 281.

Todd, D. K., 1980. Groundwater Hydrology, 2nd edn (New York: John Wiley and Sons). $\mathrm{P}_{\mathrm{P}}$.111-163.

Verstappen, H. T., 1983. Applied geomorphology. Geomorphologic Survey for Environmental Development, International Institute for Aerial Survey and Earth Science (I.T.C.) Enschede, the Netherlands. Pp. 434.

Vittala, S. S., S. Govindaiah and H. H. Gowda 2005. Evaluation of groundwater potential zones in the sub-watersheds of North Pennar river basin around Pavagada, Karnataka, India using remote sensing and GIS techniques. Journal of Indian Society of Remote Sensing. 33(4): 483-493.

Waikar, M. L., and Nilawar, A. P. 2014. Identification of groundwater potential zone using Remote Sensing and GIS Technique. International Journal of Innovative Research in Science, Engineering and Technology. 3(5): 12163-12174.

\section{How to cite this article:}

Savita, R.S., H.K. Mittal, U. Satishkumar, P.K. Singh, K.K. Yadav, H.K. Jain, S.M. Mathur and Sham Davande. 2018. Delineation of Groundwater Potential Zones using Remote Sensing and GIS Techniques in Kanakanala Reservoir Subwatershed, Karnataka, India. Int.J.Curr.Microbiol.App.Sci. 7(01): 273-288. doi: https://doi.org/10.20546/ijcmas.2018.701.030 